\title{
Marinobacter algicola sp. nov., isolated from laboratory cultures of paralytic shellfish toxin- producing dinoflagellates
}

Correspondence
David H. Green
david.green@sams.ac.uk

The genus Marinobacter was first proposed in 1992 to accommodate a novel Gram-negative, aerobic, halophilic gammaproteobacterium capable of degrading a variety of hydrocarbons (Gauthier et al., 1992). The type species, Marinobacter hydrocarbonoclasticus, was isolated from coastal waters, and since then a further 12 species of Marinobacter have been recognized. These were isolated from various locations such as an offshore oil-well head (Huu et al., 1999), a coastal thermal spring (Shieh et al., 2003), temperate (Yoon et al., 2004) and Antarctic (Shivaji et al.,

Published online ahead of print on 28 October 2005 as DOI 10.1099/ ijs.0.63447-0.

\footnotetext{
Abbreviation: PSTs, paralytic shellfish toxins.

The GenBank/EMBL/DDBJ accession numbers for the 16S rRNA gene sequences of strains DG893 ${ }^{\top}, \mathrm{DG} 1136$ and ATAM407-13 are AY258110, AY258116 and AJ294359, respectively.

A transmission electron micrograph of cells of DG893 ${ }^{\top}$ and a table detailing the cellular fatty acid composition of the three novel strains and the type strains of other Marinobacter species are available as supplementary material in IJSEM Online.
}

2005) sea water, saline soils (Martín et al., 2003) and marine sediments (Gorshkova et al., 2003; Romanenko et al., 2005). To date, only Marinobacter bryozoorum $50-11^{\mathrm{T}}$ has an identifiable biological source, having been isolated from homogenized bryozoan tissue (Romanenko et al., 2005).

The bacterial flora associated with the dinoflagellates Gymnodinium catenatum Graham and Alexandrium tamarense (Lebour) Balech have been proposed to be involved in producing a potent suite of neurotoxins, the paralytic shellfish toxins (PSTs), produced by these algae (Gallacher et al., 1997; Kodama et al., 1990). As a part of the work to understand the relationship between the bacterial flora of PST-producing dinoflagellates and PST production, we identified bacterial isolates with a phylogenetic affiliation to $M$. hydrocarbonoclasticus in laboratory cultures of these dinoflagellates that formed a discrete phylogenetic cluster (Green et al., 2004; Hold et al., 2001). The phylogenetic clustering and frequency of occurrence in laboratory cultures was suggestive of a specific association between the dinoflagellate and the M. hydrocarbonoclasticus-like isolates (Green et al., 2004; Hold et al., 2001). Bacterial isolates 
$\mathrm{DG} 83^{\mathrm{T}}$ and DG1136 were isolated from G. catenatum YC499B15 (recovered from the Yellow Sea, Korea) and G. catenatum GC21V (recovered from the Ria de Vigo, Spain), respectively, by serial dilution on a low-concentration marine agar (ZM/10; Green et al., 2004). ATAM407-13 was isolated from Alexandrium tamarense NEPCC 407 (recovered from Jericho Beach, Vancouver, Canada) by culture on marine 2216 agar (Difco). The isolates were grown aerobically at $18-20^{\circ} \mathrm{C}$ for $1-3$ weeks and then stored frozen at $-80^{\circ} \mathrm{C}$ in marine broth (Difco) supplemented with $20 \%$ glycerol (v/v).

Phenotypic examination of the isolates typically used colonies grown for $48-72 \mathrm{~h}$ on marine 2216 agar at $30^{\circ} \mathrm{C}$, streaked from ZM/10 marine agar slopes. M. hydrocarbonoclasticus NCIMB 1967 (=ATCC 27132), Marinobacter aquaeolei NCIMB $13596^{\mathrm{T}}$, Marinobacter flavimaris DSM $16070^{\mathrm{T}}$ and Marinobacter lipolyticus NCIMB $13907^{\mathrm{T}}$ were used for comparison, all maintained as above. Gram reaction and cell morphology of the strains were observed by light microscopy, and negatively stained whole cells were viewed by transmission electron microscopy on a JEOL-100SX (Beveridge et al., 1994). Catalase and oxidase activity, utilization of Tweens 40 and 80 and casein and starch hydrolysis were also determined as described by Smibert \& Krieg (1994). Nitrate reduction, indole production, arginine dihydrolase, urease, gelatin liquefaction, $\beta$-glucosidase and $\beta$-galactosidase activity were examined using API 20NE strips (Vitek-bioMérieux) inoculated with colonies suspended in $3 \% \mathrm{NaCl}(\mathrm{w} / \mathrm{v})$. The ability of the isolates to utilize a range of organic substrates was determined using 96-well Biolog GN MicroPlates as described by Smith et al. (2002). The ability of the strains to utilize aliphatic hydrocarbons was determined by growing the strains on a synthetic sea-water agar (SM1; Yakimov et al., 1998), varying only in that $\mathrm{NH}_{4} \mathrm{NO}_{3}$ was used as the nitrogen source. Bacteria were streaked onto the agar, and hydrocarbon was supplied in the vapour phase by adding $200 \mu \mathrm{l}$ of either $\mathrm{n}$-tetradecane (Sigma) or n-hexadecane (Sigma) as the sole carbon source to a sterile piece of Whatman Qualitative 1 filter paper placed in the lid of the Petri dish. Growth was assessed after 3 weeks incubation at $25^{\circ} \mathrm{C}$. Utilization of hydrocarbon was assessed based on the amount of growth relative to cells streaked onto the same agar but without any added carbon source.

Strains DG893 ${ }^{\mathrm{T}}$, DG1136 and ATAM407-13 were all similar in terms of their cell morphology, growth and phenotypic characteristics (see the species description, Table 1 and Supplementary Fig. S1 available in IJSEM Online). The three novel strains all demonstrated an ability to utilize a comparatively wide range of organic compounds as their sole carbon and energy source compared with those utilized by the other Marinobacter type strains examined. Discriminatory phenotypic characteristics are given in Table 1. DG893 ${ }^{\mathrm{T}}$, DG1136 and ATAM407-13 were all positive for the utilization of Tweens 40 and 80 , glycerol, dextrin, glycogen, glucose, methyl pyruvate, acetate, citrate, $\alpha$-hydroxybutyrate, $\beta$-hydroxybutyrate, DL-lactate, propionate, succinate, bromosuccinate, D-alanine, L-glutamate, L-leucine, L-proline and L-pyroglutamate. All strains were negative for the utilization of $\alpha$-cyclodextrin, $N$-acetyl-D-galactosamine, $\mathrm{N}$-acetyl-D-glucosamine, adonitol, L-arabinose, D-arabitol, cellobiose, erythritol, L-fucose, D-galactose, gentiobiose, myo-inositol, $\alpha$-lactose, $\alpha$-D-lactose lactulose, D-mannose, $D$-melibiose, methyl $\beta$-D-glucoside, psicose, D-raffinose, L-rhamnose, D-sorbitol, sucrose, D-trehalose, turanose, xylitol, formic acid, D-galactonic acid lactone, D-galacturonic acid, D-glucosaminic acid, D-glucuronic acid, p-hydroxyphenylacetic acid, itaconic acid, malonic acid, quinic acid, D-saccharic acid, sebacic acid, succinamic acid, glucuronamide, alaninamide, L-alanyl glycine, L-aspartic acid, glycyl L-aspartic acid, glycyl L-glutamic acid, L-histidine, hydroxyL-proline, L-ornithine, DL-serine, L-threonine, DL-carnitine, $\gamma$-aminobutyric acid, urocanic acid, inosine, uridine, thymidine, phenyl ethylamine, putrescine, $\alpha$-DL-glycerol phosphate, glucose 1-phosphate and glucose 6-phosphate.

Consistent with all recognized Marinobacter species, $\mathrm{Na}^{+}$ was essential for growth, and $\mathrm{K}^{+}$would not suffice in its place. Of the $\mathrm{NaCl}$ concentrations tested $[0,1,3,6,9,12,15$, $20,25 \%(\mathrm{w} / \mathrm{v})]$, growth was only observed at $\geqslant 1 \% \mathrm{NaCl}$ (w/v), and at up to $9 \%$ for DG1136 and ATAM407-13, and up to $12 \%$ for DG893 $3^{\mathrm{T}}$. The range of $\mathrm{pH}$ over which all strains grew was consistent with other Marinobacter species. Growth was observed between $\mathrm{pH} 5$ and 10 with an observed optimum of $\mathrm{pH} 7 \cdot 5$ for all strains. Anaerobic growth was observed to occur in all strains in the presence of nitrate and acetate, but not glucose. The temperatures examined for growth were $5,10,18,25,30,37,40$ and $45^{\circ} \mathrm{C}$. The upper temperature at which growth was observed was $40^{\circ} \mathrm{C}$, while growth, albeit slow, occurred at $5{ }^{\circ} \mathrm{C}$ (Table 1). The optimal temperature range for growth of all strains was $25-30{ }^{\circ} \mathrm{C}$.

Strains DG893 ${ }^{\mathrm{T}}$, DG1136 and ATAM407-13 were capable of growth on n-tetradecane and n-hexadecane as their sole carbon source. Growth of ATAM407-13 on these two hydrocarbon sources was weaker than that of $\mathrm{DG} 893^{\mathrm{T}}$ and DG1136, and all three strains showed a preference for n-tetradecane. All strains showed an ability to grow on synthetic sea-water agar without any added carbon source, and formed shallow $(<1 \mathrm{~mm})$, colony-sized depressions in the agar; subsurface growth could be seen radiating out from beneath each colony. However, there was no evidence of softening of the agar surrounding the colony. This observation indicates the capacity for oligotrophic growth and/or the ability to utilize agar as a carbon source. Agarolytic activity was not otherwise observed in any of the strains when grown on more complex media, marine 2216 agar or the more dilute version, $\mathrm{ZM} / 10$ agar.

The 16S rRNA genes were sequenced as described by Green et al. (2004) and Hold et al. (2001). Taxonomic assignment based on the $16 \mathrm{~S}$ rRNA gene sequences was initially performed using the Sequence Match facility of the Ribosomal Database Project II (Cole et al., 2003). Multiple alignments were performed using CLUSTAL_X (Thompson et al., 1997). 
Table 1. Differential phenotypic characteristics between Marinobacter algicola sp. nov. and the type strains of selected Marinobacter species

Strains: 1, DG893 ${ }^{\mathrm{T}}$, DG1136 and ATAM407-13; 2, M. flavimaris SW-145 $;$; , M. lipolyticus SM19 ${ }^{\mathrm{T}}$; 4, M. bryozoorum 50-11 ${ }^{\mathrm{T}}$; 5, M. sediminum $\mathrm{R}^{\mathrm{T}}{ }^{\mathrm{T}}$; 6, M. hydrocarbonoclasticus ATCC $49840^{\mathrm{T}}$; 7, M. aquaeolei NCIMB $13596^{\mathrm{T}}$. Additional data for type strains were taken from Gauthier et al. (1992), Huu et al. (1999), Martín et al. (2003), Yoon et al. (2004) and Romanenko et al. (2005). +, Positive; -, negative; $\mathrm{V}$, variable response.

\begin{tabular}{|c|c|c|c|c|c|c|c|}
\hline Characteristic & 1 & 2 & 3 & 4 & 5 & 6 & 7 \\
\hline Nitrate reduced to nitrite & - & + & - & + & - & + & + \\
\hline \multicolumn{8}{|l|}{ Growth: } \\
\hline Minimum temperature $\left({ }^{\circ} \mathrm{C}\right)$ & 5 & 4 & 15 & 7 & 4 & 10 & 13 \\
\hline Maximum temperature $\left({ }^{\circ} \mathrm{C}\right)$ & 40 & 45 & 40 & 42 & 42 & 45 & 50 \\
\hline $\mathrm{NaCl}$ range $(\%)$ & $1-12^{*}$ & $1-20$ & $1-15$ & $1-18$ & $0 \cdot 5-18$ & $1-20$ & $1-20$ \\
\hline \multicolumn{8}{|l|}{ Enzyme activity: } \\
\hline Amylase & + & - & - & - & - & - & - \\
\hline Urease & $\mathrm{V} \dagger$ & - & - & - & - & - & + \\
\hline Arginine dihydrolase & + & - & - & - & - & - & - \\
\hline \multicolumn{8}{|l|}{ Utilization of: } \\
\hline Glycerol & + & - & - & + & + & - & - \\
\hline D-Fructose & + & + & + & - & - & - & - \\
\hline D-Glucose & + & - & + & - & + & - & - \\
\hline Maltose & + & - & + & - & - & - & - \\
\hline D-Mannitol & $\mathrm{V} \ddagger$ & - & + & - & - & - & - \\
\hline Sucrose & - & - & - & + & + & + & + \\
\hline Citric acid & + & - & - & - & - & + & $-\S$ \\
\hline DL-Lactic acid & + & - & - & - & - & + & + \\
\hline cis-Aconitic acid & + & - & - & - & - & + & + \\
\hline D-Gluconic acid & + & + & + & - & - & - & - \\
\hline L-Alanine & $\mathrm{v} \dagger$ & - & - & - & - & - & + \\
\hline L-Leucine & + & - & - & - & - & - & + \\
\hline L-Phenylalanine & + & - & - & - & - & - & - \\
\hline L-Proline & + & + & - & - & - & + & + \\
\hline DNA G $+C$ content $(\mathrm{mol} \%)$ & $54-55$ & 58 & 57 & $59 \cdot 6$ & $56 \cdot 5$ & 53 & 56 \\
\hline
\end{tabular}

${ }^{*} \mathrm{NaCl}$ tolerance was $1-12 \%$ for strain DG893 ${ }^{\mathrm{T}}$ and $1-9 \%$ for strains DG1136 and ATAM407-13. $\nmid$ DG893 ${ }^{\mathrm{T}}$ and DG1136 were both positive and ATAM407-13 was negative. $\ddagger D G 893^{\mathrm{T}}$ was positive whereas DG1136 and ATAM407-13 were negative. $\S$ Huu et al. (1999) reported citrate utilization as positive.

Alignments were manually corrected and ambiguous regions were masked from the analysis. The program PAUP4.0* (Swofford, 2001) was used to construct the distance tree based on the neighbour-joining algorithm (Saitou \& Nei, 1987) according to the maximum-likelihood model, and bootstrap support for the inferred tree was established by resampling 1000 datasets by the neighbour-joining method (Saitou \& Nei, 1987). Alcanivorax borkumensis $\mathrm{SK} 2^{\mathrm{T}}$ (GenBank accession no. Y12579) and Alcanivorax venustensis ISO4 ${ }^{\mathrm{T}}$ (GenBank accession no. AF328762) were used as the outgroup.

16S rRNA gene sequence analysis showed that $\mathrm{DG} 893^{\mathrm{T}}$, DG1136 and ATAM407-13 were most closely related to $M$. flavimaris $\mathrm{SW}-145^{\mathrm{T}}(97 \cdot 8,97 \cdot 5$ and $97 \cdot 5 \%$, respectively) and M. lipolyticus $\mathrm{SM}_{1}{ }^{\mathrm{T}}(97 \cdot 1,97 \cdot 2$ and $97 \cdot 3$, respectively); lower similarities were observed to the type strains of other Marinobacter species, such as Marinobacter sediminum $\mathrm{R} 65^{\mathrm{T}}$ (96.4-96.6\%), M. hydrocarbonoclasticus ATCC 27132 $(94 \cdot 2-94 \cdot 3 \%)$ and M. aquaeolei $\mathrm{VT}^{\mathrm{T}}(94 \cdot 2-94 \cdot 4 \%) .16 \mathrm{~S}$ rRNA gene sequence similarity of DG893 ${ }^{\mathrm{T}}$ to DG1136 and ATAM407-13 was $99 \cdot 3$ and $99 \cdot 7 \%$, respectively, while DG1136 and ATAM407-13 had a sequence similarity of $99 \cdot 9 \%$. As the sequence divergence of DG893 ${ }^{\mathrm{T}}$, DG1136 and ATAM407-13 from the closest phylogenetically related Marinobacter species (M. flavimaris) was $>2 \%$, this supports the proposal that they may represent a novel species, and as DG893 ${ }^{\mathrm{T}}$, DG1136 and ATAM407-13 were all $\geqslant 99.3 \%$ similar to one another, this is consistent with these strains belonging to a single species (Stackebrandt \& Goebel, 1994). Phylogenetic analysis (Fig. 1) shows that DG893 $^{\mathrm{T}}$, DG1136 and ATAM407-13 form a distinct and 


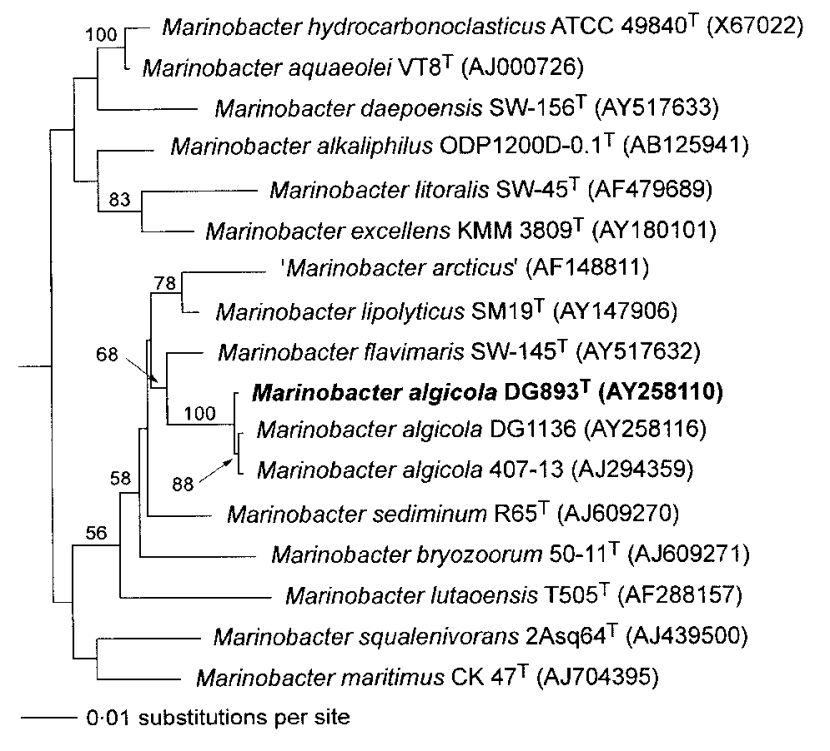

Fig. 1. Phylogenetic dendrogram based on the nearly complete 16S rRNA gene sequences of Marinobacter algicola sp. nov. and the type strains of other Marinobacter species (Alcanivorax borkumensis and $A$. venustensis were used as the outgroup; not shown). The tree was constructed by neighbour-joining using the maximum-likelihood model and bootstrap support (1000 replicates each) based on neighbour-joining. Bar, 0.01 nucleotide substitutions per site.

supported phylogenetic cluster separate from M. flavimaris SW- $145^{\mathrm{T}}$ and M. lipolyticus SM19 ${ }^{\mathrm{T}}$, the two closest phylogenetic relatives. It also shows that the three strains comprise a coherent phylogenetic cluster within the genus Marinobacter.

Whole-genome DNA-DNA hybridization studies were conducted between DG893 ${ }^{\mathrm{T}}$, DG1136, ATAM407-13, M. hydrocarbonoclasticus NCIMB 1967, M. aquaeolei NCIMB $13596^{\mathrm{T}}$, M. lipolyticus NCIMB $13907^{\mathrm{T}}$ and M. flavimaris DSM $16070^{\mathrm{T}}$. Genomic DNA was extracted from washed, harvested cells grown in marine 2216 broth for $24 \mathrm{~h}$ at $30^{\circ} \mathrm{C}$ according to the method described by Marmur (1961). Analysis of the $\mathrm{G}+\mathrm{C}$ content and DNA-DNA hybridization were both performed essentially as described by Bowman et al. (1998). DG893 ${ }^{\mathrm{T}}$ showed DNA-DNA reassociation values of 35, 39, 42 and $35 \%$ with $M$. hydrocarbonoclasticus, M. aquaeolei, M. lipolyticus and M. flavimaris, respectively. As these values were all $<70 \%$, this delineates DG893 ${ }^{\mathrm{T}}$ from the other Marinobacter type strains, and supports the proposal that DG893 ${ }^{\mathrm{T}}$ represents a novel species (Stackebrandt \& Goebel, 1994). The DNA-DNA reassociation values of $\mathrm{DG}_{893}{ }^{\mathrm{T}}$ with DG1136 and ATAM407-13 were 95 and $83 \%$, respectively, and the reassociation value of DG1136 to ATAM407-13 was $90 \%$. These DNA-DNA hybridization levels $(>70 \%)$ support the proposal that DG893 ${ }^{\mathrm{T}}$, DG1136 and ATAM407-13 represent a single species (Stackebrandt \& Goebel, 1994). The DNA G + C content of DG893 ${ }^{\mathrm{T}}$, DG1136 and ATAM407-13 was 55, 55 and $54 \mathrm{~mol} \%$, respectively, consistent with values reported for the type strains of other Marinobacter species (Table 1).

Cellular fatty acid and isoprenoid quinone content were determined for cell mass grown on marine 2216 agar and broth, respectively, for $48 \mathrm{~h}$ at $30^{\circ} \mathrm{C}$. Fatty acid methyl esters were extracted and prepared according to standard protocols as described for the MIDI Microbial Identification System (Sasser, 1990). Cellular fatty acid content was analysed with the MIDI Microbial Identification system. Results are available as Supplementary Table S1 in IJSEM Online. The fatty acid composition was generally consistent with that of other Marinobacter type strains, although DG893 ${ }^{\mathrm{T}}$, DG1136 and ATAM407-13 differed in having increased abundances of $\mathrm{C}_{16: 1} \omega 07 \mathrm{c} /$ iso- $\mathrm{C}_{15: 0} 2-\mathrm{OH}$ (summed feature MIDI fatty acid methyl ester analysis), $\mathrm{C}_{16: 0} 10$-methyl and $\mathrm{C}_{18: 1} \omega 7 c$ and a reduced abundance of $\mathrm{C}_{16: 1} \omega 9 c$ (Supplementary Table S1). The isoprenoid quinone content of the three novel strains, with $M$. hydrocarbonoclasticus NCIMB 1967 and M. flavimaris DSM $16070^{\mathrm{T}}$ as reference strains, was determined by reversed-phase HPLC using an Eclipse XDBC18 column (Agilent Technologies), essentially as described by Komagata \& Suzuki (1987). The principal isoprenoid quinone was shown to be ubiquinone-9 (Q-9), consistent with other Marinobacter type strains except Marinobacter lutaoensis, which contains ubiquinone-8 (Shieh et al., 2003).

On the basis of 16S rRNA gene sequence analysis, DNADNA hybridization, phenotypic characteristics and chemotaxonomic properties, DG893 ${ }^{\mathrm{T}}$, DG1136 and ATAM407-13 are proposed as three related strains of a novel species within the genus Marinobacter, for which the name Marinobacter algicola sp. nov. is proposed.

\section{Description of Marinobacter algicola sp. nov.}

Marinobacter algicola [al.gi'co.la. L. n. alga -ae an alga (seaweed, dinoflagellate etc.); L. suff. -cola from L. n. incola an inhabitant; N.L. fem. n. algicola an inhabitant of algae].

Gram-negative, oxidase- and catalase-positive, non-sporeforming rods, $1.6-2.5 \times 0 \cdot 45-0.55 \mu \mathrm{m}$, occurring as single cells, in pairs or as short chains of cells. Motile by means of a single, non-sheathed, polar flagellum. Colonies on marine 2216 agar at $25-30^{\circ} \mathrm{C}$ after $72 \mathrm{~h}$ are cream, circular (1$2 \mathrm{~mm}$ ), smooth, convex and shiny with entire edges. Older colonies change in shape from convex to umbonate and become light beige in the centre with pale margins. Growth requires $\mathrm{Na}^{+}$and occurs across a range of total $\mathrm{NaCl}(\mathrm{w} / \mathrm{v})$ of $1-9 \%$ for DG1136 and ATAM407-13 and $1-12 \%$ for DG893 ${ }^{\mathrm{T}}$; optimal growth is between 3 and $6 \%(\mathrm{w} / \mathrm{v}) \mathrm{NaCl}$. Growth occurs at $5-40{ }^{\circ} \mathrm{C}$, with an optimal temperature of $25-30{ }^{\circ} \mathrm{C}$, and over a $\mathrm{pH}$ range of $5-10$, with an optimum of $\mathrm{pH} 7 \cdot 5$. Nitrate and nitrite are not reduced. Growth is aerobic, but anaerobic growth in the presence of nitrate and acetate, but not glucose, is observed. Tweens 40 and 80 and starch are hydrolysed, but gelatin and casein are not. Strains $\mathrm{DG}_{893}{ }^{\mathrm{T}}$ and DG1 136 are urease-positive, but ATAM407-13 is not. All strains identified to date are positive for arginine 
dihydrolase activity, but negative for indole, $\beta$-glucosidase and $\beta$-galactosidase activity. All strains utilize $\mathrm{n}$-hexadecane and n-tetradecane and other carbon sources as sole carbon and energy sources, as indicated in Table 1 and the main text. The predominant cellular fatty acids are $\mathrm{C}_{16: 0}$ $(22 \cdot 0-25 \cdot 5 \%), \mathrm{C}_{16: 1} \omega 7 c /$ iso- $\mathrm{C}_{15: 0} 2-\mathrm{OH}(19 \cdot 5-20 \cdot 5 \%)$, $\mathrm{C}_{18: 1} \omega 9 c(9 \cdot 7-11 \cdot 5 \%)$ and $\mathrm{C}_{12: 0} 3-\mathrm{OH}(8 \cdot 7-10 \cdot 0 \%)$. Q-9 is the principal isoprenoid quinone.

The type strain is DG893 ${ }^{\mathrm{T}}\left(=\mathrm{DSM} 16394^{\mathrm{T}}=\mathrm{NCIMB}\right.$ $\left.14009^{\mathrm{T}}\right)$. The DNA $\mathrm{G}+\mathrm{C}$ content of the type strain is $55 \mathrm{~mol} \%$. Strains DG893 ${ }^{\mathrm{T}}$ and DG1136 were isolated from laboratory cultures of the dinoflagellate Gymnodinium catenatum (from Korea and Spain, respectively) and ATAM407-13 from the dinoflagellate Alexandrium tamarense (from Canada).

\section{Acknowledgements}

Strain ATAM407-13 was kindly donated for analysis by S. Gallacher and G. catenatum YC499B15 was kindly donated by Mr T. G. Park. We thank the National Collection of Plant-Pathogenic Bacteria (UK) for performing cellular fatty acid analysis. D. H. G. was supported in part by a post-doctoral fellowship from the New Zealand Foundation for Research, Science and Technology. This work was supported in part by funds to E. A. S. from Fisheries Research Services (UK).

\section{References}

Beveridge, T. J., Popkin, T. J. \& Cole, R. M. (1994). Electron microscopy. In Methods for General and Molecular Bacteriology, pp. 42-71. Edited by P. Gerhardt, R. G. E. Murray, W. A. Wood \& N. R. Krieg. Washington, DC: American Society for Microbiology.

Bowman, J. P., McCammon, S. A., Brown, J. L. \& McMeekin, T. A. (1998). Glaciecola punicea gen. nov., sp. nov. and Glaciecola pallidula gen. nov., sp. nov.: psychrophilic bacteria from Antarctic sea-ice habitats. Int J Syst Bacteriol 48, 1213-1222.

Cole, J. R., Chai, B., Marsh, T. L. \& 8 other authors (2003). The Ribosomal Database Project (RDP-II): previewing a new autoaligner that allows regular updates and the new prokaryotic taxonomy. Nucleic Acids Res 31, 442-443.

Gallacher, S., Flynn, K. J., Franco, J. M., Brueggemann, E. E. \& Hines, H. B. (1997). Evidence for production of paralytic shellfish toxins by bacteria associated with Alexandrium spp. (Dinophyta) in culture. Appl Environ Microbiol 63, 239-245.

Gauthier, M. J., Lafay, B., Christen, R., Fernandez, L., Acquaviva, M., Bonin, P. \& Bertrand, J.-C. (1992). Marinobacter hydrocarbonoclasticus gen. nov., sp. nov., a new extremely halotolerant, hydrocarbondegrading marine bacterium. Int J Syst Bacteriol 42, 568-576.

Gorshkova, N. M., Ivanova, E. P., Sergeev, A. F., Zhukova, N. V., Alexeeva, Y., Wright, J. P., Nicolau, D. V., Mikhailov, V. V. \& Christen, R. (2003). Marinobacter excellens sp. nov., isolated from sediments of the Sea of Japan. Int J Syst Evol Microbiol 53, 2073-2078.

Green, D. H., Llewellyn, L. E., Negri, A. P., Blackburn, S. I. \& Bolch, C. J. S. (2004). Phylogenetic and functional diversity of the cultivable bacterial community associated with the paralytic shellfish poisoning dinoflagellate Gymnodinium catenatum. FEMS Microbiol Ecol 47, 345-357.

Hold, G. L., Smith, E. A., Rappe, M. S. \& 7 other authors (2001). Characterisation of bacterial communities associated with toxic and non-toxic dinofagellates: Alexandrium spp. and Scrippsiella trochoidea. FEMS Microbiol Ecol 37, 161-173.

Huu, N. B., Denner, E. B. M., Dang, T. C. H., Wanner, G. \& StanLotter, H. (1999). Marinobacter aquaeolei sp. nov., a halophilic bacterium isolated from a Vietnamese oil-producing well. Int J Syst Bacteriol 49, 367-375.

Kodama, M., Ogata, T., Sakamoto, S., Sato, S., Honda, T. \& Miwatani, T. (1990). Production of paralytic shellfish toxins by a bacterium Moraxella sp. isolated from Protogonyaulax tamarensis. Toxicon 28, 707-714.

Komagata, K. \& Suzuki, K. (1987). Lipids and cell-wall analysis in bacterial systematics. Methods Microbiol 19, 161-203.

Marmur, J. (1961). A procedure for the isolation of deoxyribonucleic acid from micro-organisms. J Mol Biol 3, 208-218.

Martín, S., Márquez, M. C., Sánchez-Porro, C., Mellado, E., Arahal, D. R. \& Ventosa, A. (2003). Marinobacter lipolyticus sp. nov., a novel moderate halophile with lipolytic activity. Int J Syst Evol Microbiol 53, 1383-1387.

Romanenko, L. A., Schumann, P., Rohde, M., Zhukova, N. V., Mikhailov, V. V. \& Stackebrandt, E. (2005). Marinobacter bryozoorum sp. nov. and Marinobacter sediminum sp. nov., novel bacteria from the marine environment. Int J Syst Evol Microbiol 55, 143-148.

Saitou, N. \& Nei, M. (1987). The neighbor-joining method: a new method for reconstructing phylogenetic trees. Mol Biol Evol 4, 406-425.

Sasser, M. (1990). Identification of bacteria by gas chromatography of cellular fatty acids. Newark, DE: MIDI Inc.

Shieh, W. Y., Jean, W. D., Lin, Y. T. \& Tseng, M. (2003). Marinobacter lutaoensis sp. nov., a thermotolerant marine bacterium isolated from a coastal hot spring in Lutao, Taiwan. Can J Microbiol 49, 244-252.

Shivaji, S., Gupta, P., Chaturvedi, P., Suresh, K. \& Delille, D. (2005). Marinobacter maritimus sp. nov., a psychrotolerant strain isolated from sea water off the subantarctic Kerguelen islands. Int J Syst Evol Microbiol 55, 1453-1456.

Smibert, R. M. \& Krieg, N. R. (1994). Phenotypic characterization. In Methods for General and Molecular Bacteriology, pp. 607-654. Edited by P. Gerhardt, R. G. E. Murray, W. A. Wood \& N. R. Krieg. Washington, DC: American Society for Microbiology.

Smith, E. A., Mackintosh, F. H., Grant, F. \& Gallacher, S. (2002). Sodium channel blocking (SCB) activity and transformation of paralytic shellfish toxins (PST) by dinoflagellate-associated bacteria. Aquat Microb Ecol 29, 1-9.

Stackebrandt, E. \& Goebel, B. M. (1994). Taxonomic note: a place for DNA-DNA reassociation and 16S rRNA sequence analysis in the present species definition in bacteriology. Int J Syst Bacteriol 44, 846-849.

Swofford, D. L. (2001). PAUP - Phylogenetic Analysis Using Parsimony and other Methods, 4th edn. Sunderland, MA: Sinauer Associates.

Thompson, J. D., Gibson, T. J., Plewniak, F., Jeanmougin, F. \& Higgins, D. G. (1997). The CLUSTAL_X windows interface: flexible strategies for multiple sequence alignment aided by quality analysis tools. Nucleic Acids Res 25, 4876-4882.

Yakimov, M. M., Golyshin, P. N., Lang, S., Moore, E. R. B., Abraham, W.-R., Lünsdorf, H. \& Timmis, K. N. (1998). Alcanivorax borkumensis gen. nov., sp. nov., a new, hydrocarbon-degrading and surfactantproducing marine bacterium. Int J Syst Bacteriol 48, 339-348.

Yoon, J. H., Yeo, S. H., Kim, I. G. \& Oh, T. K. (2004). Marinobacter flavimaris sp. nov. and Marinobacter daepoensis sp. nov., slightly halophilic organisms isolated from sea water of the Yellow Sea in Korea. Int J Syst Evol Microbiol 54, 1799-1803. 